\title{
System-Spanning Values Work and Entrepreneurial Growth in Family Firms
}

\author{
Johanna Raitis \\ Turku University, School of Economics \\ 20014 Turun yliopisto, Turku, Finland \\ johanna.raitis@utu.fi \\ Innan Sasaki \\ Warwick Business School, University of Warwick \\ CV47AL, Scarman Rd, Coventry, UK \\ Innan.Sasaki@wbs.ac.uk \\ Josip Kotlar (corresponding author) \\ Politecnico di Milano, School of Management \\ Via R. Lambruschini 4/B, 20156 Milano (Italy) \\ josip.kotlar@polimi.it
}

Paper accepted for publication in Journal of Management Studies (11/2020)

Acknowledgments: This manuscript benefited from developmental feedback by several scholars in the entrepreneurship and family business research areas, and we particularly acknowledge Tor Hernes (Copenhagen Business School) and Davide Ravasi (UCL School of Management) for their comments on earlier versions of the article. We also thank the Editors and the participants of the "Corporate Entrepreneurship and Family Business: Learning across disciplines" workshop (University of Bergamo, December 2018) for their precious comments and discussions on an earlier version of the paper. We acknowledge the financial support provided by the Finnish Cultural Foundation and the Jenny and Antti Wihuri Foundation, in addition to Niina Nummela and Turku School of Economics. Finally, we thank Ponsse Plc. for the continuous support and cooperation for the project. 


\title{
System-Spanning Values Work and Entrepreneurial Growth in Family Firms
}

\begin{abstract}
Culture and values are key drivers of corporate entrepreneurship in early stages of family firm development, but value conflicts often arise over time that progressively inhibit their entrepreneurial efforts. How can family firms reconcile conflicting values to sustain corporate entrepreneurship over time? Our 45-year longitudinal case study of a large global family firm shows that family business leaders' practices of invoking and flexibly using family and business values were crucial to achieve sustained entrepreneurial behaviour and growth over an extended period of time. We theorize these efforts as system-spanning values work enfolding through specific family, business, and temporal mechanisms. By identifying and elucidating three types of values work (i.e., rooting, revitalizing, and spreading), our study advances current understanding of the micro-foundations underpinning the relationship between values and entrepreneurship in family firms.
\end{abstract}

Keywords: Family firms, values, embeddedness, community, corporate entrepreneurship, growth

\section{INTRODUCTION}

Culture and values are widely acknowledged as key drivers of corporate entrepreneurship, as they profoundly shape firms' ability to change and adapt to the external environment (Hornsby, Kuratko, and Montagno, 1999; Morris and Schindehutte, 2005). The role of culture is particularly salient in family firms (e.g., Eddleston, Kellermanns and Zellweger, 2012; Hall, Melin and Nordqvist, 2001; Zahra, Hayton and Salvato, 2004; Zahra, 2005), as their values are embedded in idiosyncratic social structures reflecting each family's unique history and relationship with the local community (e.g., Aldrich and Cliff, 2003). Research suggests that family-and community-embedded values are key in promoting entrepreneurial behaviour in the early stage of a family firm's lifecycle(Miller, Breton- 
Miller and Lester, 2013; Rogoff and Heck, 2003). However, over time, family firms are increasingly compelled to incorporate external values and norms that may be incompatible with their original values, giving rise to value conflicts and cultural breakdowns that impede further entrepreneurial behaviour and growth (e.g., Hjorth and Dawson, 2016; Jaskiewicz, Combs and Rau, 2016; Miller et al., 2013; Reay, Jaskiewicz and Hinings, 2015).

A small but significant stream of qualitative research has revealed that mimetic and normative pressures over time compel family firms to adopt new values in the form of institutional logics (Reay et al., 2015) or governance practices (Parada et al., 2010). Thus, existing research acknowledges that family firms' culture and values change over time throughout its interplay with external constituencies, either enabling or constraining entrepreneurial processes (Hall et al., 2001; Parada, Nordqvist and Gimeno, 2010; Reay et al., 2015). This research points to a process of "high-order learning in which old cultural patterns are continuously questioned and changed" (Hall et al., 2001). Unfortunately, yet, the practices through which family firms can manage value conflicts to sustain corporate entrepreneurship over time remain largely a black box (Hoy and Sharma, 2010; Jaskiewicz et al., 2015; Reay et al., 2015; Zahra, 2018).

To address this important research gap, we rely on a 45-year longitudinal case study (Eisenhardt and Graebner, 2007; Yin, 2009) of a large, global family firm that is still deeply embedded in the family and the local community (e.g., Aldrich and Cliff, 2003), which provided a rare opportunity to study value dynamics and their effects on corporate entrepreneurship over time. Taking a microfoundations perspective (De Massis and Foss, 2018), our study uncovered the values practices that allowed this family firm to sustain entrepreneurial behaviour over an extended period of time. This analysis reveals value tensions triggered by critical events destabilizing the family system and/or business system as the firm developed and grew (Gersick et al., 1997). Based on our analysis, we develop the new concept of system-spanning values work to describe the practices through which family business leaders can invoke and use values across the family system and the business system, as well as across different temporal orientations. Our findings highlight three types of values work - 
rooting, revitalizing, and spreading - and explain how each address value tensions and sustain entrepreneurial growth over time.

The findings presented in this paper contribute to ex tending current knowledge of the relationship between family business values and corporate entrepreneurship in family firms by providing a more nuanced understanding of value dynamics in family firms (e.g., Hall et al., 2001; Parada et al., 2010; Reay et al., 2015). This helps research move from a monolithic view of family firm culture toward a deeper appreciation of the micro-level practices that family business leaders use to encourage entrepreneurial behaviour over time. These insights also extend the concept of family business culture (e.g., Hall et al., 2001) and values work more generally (e.g., Wright, Irving and Selvan Thevatas, 2020), thereby opening up new research questions at the intersection of organizational culture and corporate entrepreneurship studies (e.g., Morris and Schindehutte, 2005).

\section{THEORETICAL BACKGROUND}

\section{Corporate Entrepreneurship across the Family Business Lifecycle}

The family business literature has long emphasized the complex dynamics underlying the entrepreneurial behaviour of family firms (Chua, Chrisman and Sharma, 1999; Harvey and Evans, 1994; Olson et al., 2003; Zachary, 2011), fuelling researchers' interest in understanding the factors that help family firms engage in corporate entrepreneurship (e.g., Hoy, 2006; Minola et al., 2016), especially over time and across stages of their development (e.g., De Massis et al., 2013; Le BretonMiller and Miller, 2013).

According to the systems perspective (Gersick et al., 1997), family firms' growth enfolds across the family and the business systems. In the early stage of their development, the family system is dominated by family founders who imprint their vision, leadership, intuitive decision-making and kinship-based relationships onto the firm (Chua, Chrisman and Chang, 2004). Family founders commonly embrace an entrepreneurial identity which promotes unified values across the family and the business system, leading to a greater entrepreneurial behaviour(Le Breton-Miller and Miller, 2013; Rogoff and Heck, 2003). Over time, however, the family system extends to new family 
members who have diverse goals and priorities (e.g., Kotlar and De Massis, 2013). Moreover, as the firm grows and becomes increasingly visible in its industry, it starts facing new pressures to adopt industry-embedded values and norms (Mazzelli, Kotlar and De Massis, 2018; Miller et al., 2013) that may be incompatible with the family's founding entrepreneurial vision (Stewart and Hitt, 2012). Research suggests that such value conflicts tend to dilute the family founders' initial entrepreneurial impulsion (Le Breton-Miller and Miller, 2013), leading to inertia and limiting further entrepreneurial behaviour (Salvato, Chirico and Sharma, 2010; Schulze, Lubatkin and Dino, 2003).

These insights align with empirical evidence showing that older family firms invest less in innovation (e.g., Chrisman and Patel, 2012), diversify less (e.g., Gómez-Mejía et al., 2010), and become increasingly risk-averse over time (De Massis et al., 2013). Similarly, research shows that family firms' entrepreneurial behaviour tends to weaken once control is passed from the founding to the later generations (e.g., Cruz and Nordqvist, 2012; De Massis et al., 2013). Notwithstanding these general trends, the question of how some family firms manage to sustain corporate entrepreneurship over extended periods of time and across multiple generations remains largely unaddressed in existing research (Miller and Le Breton-Miller, 2005; Jaskiewicz et al., 2015; Nordqvist and Melin, 2010). More specifically, as we explain below, the role of values and value dynamics in these processes remains largely unaddressed (Reay et al., 2015).

\section{Culture and Values as Drivers of Corporate Entrepreneurship over Time}

Consistent with the view that values constitute the micro-foundation of organizational culture (e.g., Giorgi, Lockwood and Glynn, 2015)ํㅓㄴ family business scholars have shown that family values have a significant bearing on family firms' entrepreneurial behaviour and performance(Dyer, 2003; Zahra et al., 2004; Zahra, 2018). The distinctive nature of family business culture and values has been widely discussed in the literature, mainly drawing on the system development (Gersick et al., 1997) and embeddedness perspectives (Aldrich and Cliff, 2003). This research suggests that family values stem from the family firm's embeddedness in the family sy stem as well as in the community where the family firm is embedded (Chua et al., 2004; Miller andLe Breton-Miller, 2005; Reay et al., 2015). 
The family business literature has also documented significant changes in family firms' culture and values over time, and as they interact with the external environment and become embedded in a larger and more complex set of systems, such as the industry. This process involves a profound "transformation of old values and the definition of new ones" (Parada et al., 2010, p. 358), as well as a growing tension between multiple and often conflicting values (e.g., Kotlar and De Massis, 2013). For instance, Dyer (1989) highlighted that community values may conflict with the more general values of newly hired professional managers who live outside the community they work in, and may have different values and goals to indigenous employees, leading to an "us versus them" mentality (p. 232). As value tensions arise, the initial family values are often seen as a burden that limits family firms' further entrepreneurial growth (e.g., Bird and Zellweger, 2017; Hjorth and Dawson, 2016). Research suggests that only few family firms are able to retain family values while engaging in corporate entrepreneurship and growth over time (e.g., Jaskiewicz et al., 2015; Lumpkin and Brigham, 2011; Parada and Dawson, 2017; Parada et al., 2010; Salvato et al., 2010). This is exemplified by the emphasis that extraordinarily long-lived family firms place on their historical values, such as the Henokiens companies in Europe (Bennedsen and Van der Heyden, 2010) and Japan's shinise companies (Sasaki, Ravasi and Micelotta, 2019).

Collectively, these studies suggest that the co-existence of family and business values may be both burden and resource for family firms, especially as they grow and develop. However, existing research provides very limited insights into how these values and entrepreneurship co-evolve in family firms over time (Hall et al., 2001; Parada et al., 2010; Zahra, 2018). Elucidating how family business leaders manage the tensions between family and business values to sustain entrepreneurial growth overtime? therefore, is as an important research question (Hoy and Sharma, 2010; Jaskiewicz et al., 2015; Reay et al., 2015). To find the answer to this theoretical conundrum, we adopt a microlevel perspective (De Massis and Foss, 2018), moving toward a deeper appreciation of the actual practices of family business leaders as they balance conflicting values to foster entrepreneurial growth across the stages of the firm's development. Also, we recognize family business as a 
complex system comprised of a "multiplicity of values" (Hinings et al., 1996, p. 888) that provide a tool kit that family business leaders can 'reproduce' in different times and spaces (Daskalaki, Fotaki and Sotiropoulou, 2018; Gehman, Treviño and Garud, 2013). We suggest that family business leaders work at the interface of the family and the business system, and can therefore exert substantial influence on both systems, thereby influencing the family firms' overarching values (e.g., Dyer, 1986).

\section{METHODS}

\section{Research Design}

Our research was initially driven by the phenomenological interest in our case company, Ponsse Plc., a unique case (Siggelkow, 2007) in the context of the family business literature. Contrary to the common assumption that, over time, family values tend to become increasingly a burden for entrepreneurial growth (e.g., Reay et al., 2015), traditional and locally rooted values have guided the strategies and daily operations of this family firm for over 45 years of continued entrepreneurial growth. Also unusual is its home base, a small village located in the countryside, which is atypical for a family firm that has become a key player in the global market. Overall, this case offered us a rare opportunity to longitudinally explore the development of corporate entrepreneurship in a family firm and track the evolution of family business values over an unusually long period of time (Zahra, 2018).

Ponsse was founded by the forest machinery entrepreneur Einari Vidgrén in 1970 in his home town, the small municipality of Vieremä in Finland. In those days, agriculture and milk production were major sources of income in Vieremä, but over the years, the municipality developed into a modern industrial region with Ponsse's lead. Today Ponsse is the largest employer in the municipality with over 500 local employees. This unusual case allowed us to establish a clear link with prior literature, as Ponsse's evolution and entrepreneurial growth reflected the family business development stages generally described in the literature (Gersick et al., 1997). Figure 1 illustrates the evolution of the family and the business systems, as well as the family firms' major 
entrepreneurial undertakings and achievements.

Specifically, tracking the business system revealed a clear pattern of entrepreneurial growth in three main stages: the start-up in 1970 and development and sale of the first high quality forest machine to a local contractor for 120,000 Finnish marks (equivalent to $€ 166,000$ ), and then building a factory to pursue high-volume manufacturing were the first steps in the company's entrepreneurial growth. With a steady increase in demand, Ponsse had 20 employees and sales amounting to $€ 1.7 \mathrm{M}$ by 1980 . Another stage of entrepreneurial growth began in 1994, when the firm started pursuing internationalization in Europe, North and South America and Russia, while simultaneously diversifying the product range and introducing new features. By 2000 , the number of employees had increased to 480 , including a growing number of international employees, and sales to $€ 120 \mathrm{M}$ of which international sales accounted for $56 \%$. By 2010 , the firm reached the maturity stage and status of a large established corporation with 825 employees and sales of more than $€ 262 \mathrm{M}$, positioning it as one of the world's leading manufacturers of forest machinery. During this stage, the firm introduced a new generation product line and sought internationalization in new, emerging markets in Asia.

These developments paralleled the evolution of the family system. The firm was initially controlled by the founder Einari (i.e., the 'controlling owner' stage), until in 1988 when his brother became the CEO, hence moving the family system to what we label as the 'sibling partnership' stage. This lasted until 1994, when the second generation, the founder's sons, began entering the firm, and the first non-family CEO was appointed.From 1994 until 2009, the founder, his sons, and non-family CEOs co-existed in the firm, which we label 'the family enterprise' stage. Then, upon the founder's death in 2010, a 'post-founder' stage began as the founder's sons became the main owners, keeping their managerial positions, while the firm continued to be run by a non-family CEO.

(Insert Figure 1 about here)

The intertwined history of the municipality and the firm over the past 45 years gave us a rare opportunity to take a longitudinal perspective to understand how the founding family values, 
embedded in the local community, were emphasized in the family-business leaders' sayings and doings over time, and how this 'values work' enabled the firm's development across the three stages of entrepreneurial growth. We relied on a longitudinal single-case design (Langley, 1999; Yin, 2009) focusing not just on singular events, but on sequences of connecting events as per Hernes' (2014) suggestion that the power of an event lies in its ability to connect to other events contributing to the making or unmaking of temporal trajectories.

\section{Data Collection}

Given the inherent difficulty of retrieving historical data, our study is largely based on retrospective interviews. We also relied on multiple sources of archival data to capture the multiple dimensions of the events, complementing the occasionally partial remembrances of informants. We took several measures to facilitate memory retrieval and to attain the depth and detail of people's remembrances (Maclean, Harvey and Clegg, 2016). To enhance recall, we conducted the interviews in the firm's guesthouse or main office. Furnished with pictures and artefacts from different eras in the firm's history, we expected the research setting and non-verbal cues to act as stimuli for the emergence of emotions and reliving experiences among retired elderly employees. Thus, before the interviews, we invited the informants to look around and dwell on their memories, later using specific pictures and artefacts to frame their memories and guide informants for a more focused and in-depth recall of events.

'Hunting memory' without distorting it requires time to obtain portrayals of past events, wherein the interviewers are active listeners and facilitators (Rubin and Rubin, 2005). Thus, rather than pushing foranswers to the interview questions, we encouraged the informants to openly discuss their experiences by expressing our genuine interest and allowing enough time for recall and memory reconstruction. With the elderly informants, we paid attention to accommodate their physical needs, such as alleviating fatigue with coffee breaks, varying the length of the interviews and conducting them in their native language.

The data collection took place in three separate rounds, ensuring focus and elaboration on the 
earlier findings. Triangulating the rich data sources - archives (1093 pages, including books and online material), interviews (46) and observations (12 days) - were a critical part of the data collection in all rounds (Pettigrew, 1990). Table I summarizes the data collected.

(Insert Table I about here)

The first round of data collection was conducted by the first author in April 2016, with the objective of comprehensively understanding the research context and identifying the key organizational events over the firm's 45-year history. The selected informants, e.g... the firm's first employee and the founder's childhood friend, were expected to have first-hand experiences, knowledge, and memories over the firm's entire life span. During the visit, the first author also retrieved books about the history of the company and the municipality, which helped to build contextual understanding and allocate the stories, memories, and events to the different developmental stages of the firm.

The second data collection round was conducted by the first and second author in August 2016, focusing in greater detail on the ideas and events that emerged in the first round. Informants were partly selected based on the suggestions of the first-round interviewees. This time, the informants were sought from various organizational positions and hierarchical levels, customers, and external business partners. In addition, an array of archival material was collected and used to piece together the objective facts, the subjective stories, and individual remembrances. For example, local newspaper articles were complemented with interview testimonials (and vice versa) to gather the perceptions and attitudes of the employees and other community members of the key events. During the second visit, the researchers were also able to follow the firm's owner through his typical week in the village, socializing with employees, customers, and locals.

The third data collection round was conducted in August and September 2017 by the first and second authors. The aim was to verify and further enrich the insights and preliminary findings. For this purpose, the informants were a mix of key people who were already interviewed in the previous rounds, in addition to some new employees, customers, and locals. The new informants were 
randomly selected and contacted on the spot in the street or in the office. These interviews were usually shorter and focused mainly on the informants' perceptions and experiences of the firm and the values. Re-interviewing was in the form of member-checking (Lincoln and Guba, 1985), where the key informants were invited to add any additional information, enrich their stories, and confirm their earlier insights. The interview data were supplemented with recent online articles and our notes from engaged observation.

\section{Data Analysis}

Temporal bracketing of entrepreneurial growth. As a first step of the analysis, we searched key events, open coding the interview transcripts, field notes, and archival material. We did so manually to "physically engag[e] with each and every fragment [of text], the slowness of the process letting [us] embed these cues more deeply in [our] memory" (Ravasi, 2017, p. 242). We initially carried out the analysis independently and separately coded the archival and interview transcripts, after which we compared and discussed them until synthesis was reached (i.e., researcher triangulation; Yin, 2009).

The bracketing of the key events led us to identify three distinct but interrelated stages (i.e., sequences of events) covering the entire lifespan of the firm. We identified transitions from discernible stages of the family firm's development, each triggered by disruptive changes in either the family or the business systems, or both, which partly resembled existing models of the family business lifecycle (e.g., Gersick et al., 1997). The first stage, which resembled the archetypal early entrepreneurial stage of family firms' development (e.g., Littunen and Hyrsky, 2000; Steier, 2007), lasted from 1970 to 1993 and was labelled 'start-up and establishment'. The second stage, from 1994 to 2009 , started when the CEO (founder's brother) passed away and the firm began internationalizing and appointing non-family CEOs. This stage resonated with previous descriptions of family firms as they cross the threshold between founder-led and professionally managed business (e.g., Zahra, 2003; Zahra and Filatotchev, 2004), hence we label it 'international expansion and professionalization'. The third stage started in 2010 with the death of the founder and the transition 
to the next generation, and was observed until 2017. By this time, the firm had reached a solid position in the market and its growth continued steadily. Thus, we label this stage 'maturity' (e.g., Jaskiewicz et al., 2015; Zellweger and Sieger, 2012).

Theoretical coding of the relationship among values. Next, we turned our attention to the different types of values that were part of the family system, business system, local community, and industry. In doing so, we borrowed theoretical frameworks from family sy stem theory (Gersick et al., 1997; Kepner, 1983), and the culture-as-tool-kit perspective, which supported our initial observation that values are embedded in broader socio-cultural value systems (Swidler, 1986; Weber, 2005). These theories helped us to identify and categorise values and their origins, as well as to understand the relationships among them (cf. Maxwell and Miller, 2008). For example, we observed that values such hardwork, equality, and humbleness originated from the local community, and were espoused by the family and became an integral part of the family values. By contrast, values such as high quality, innovativeness, customer-centricity, and to be the best in the business were new values and introduced into the business by the founder based on his interaction with broader industry stakeholders. We also noted that as the family firm moved from one stage of development to another, the changes in the family, the business and the community values triggered value tensions and conflicts in the family firm. These value tensions became apparent in our data through the narratives of the family members, employees, and locals.

Theorizing values work. The analysis above allowed us to theorize how family business leaders managed the value tension in each stage to reconcile the family and business systems, and sustained further development and growth. At this point, our interest started to converge around the concept of values work (Gehman et al., 2013), and we began recognizing three distinct mechanisms - family, business, and temporal mechanisms - that together provided an accurate description and explanation of how family business leaders managed to resolve value tensions and boost the family firm's entrepreneurial behaviour. The interactions among these mechanisms represent the focus of our theoretical development, which is illustrated in Figure 2; additional evidence is presented in Tables 
II, III, and IV in the Appendix.

(Insert Figure 2 about here)

\section{FINDINGS}

We present our findings according to the temporal sequence of events, highlighting the specific value tensions emerging in each stage and the actions undertaken to manage them and sustain continued entrepreneurial growth. Specifically, in Stage 1, we found that the business value introduced by the founder upon the firm's establishment (to be the best in the business) clashed with the conventional family value of humbleness. In Stage 2, as the founder's brother, the CEO passed away and the firm began internationalization and professionalization, the conventional family value of equality clashed with the non-family CEO's attempts to introduce a value prevailing in the industry: hierarchical leadership. Finally, in Stage 3, after the founder passed away, we found that the younger generation started to increasingly embrace the value of individualism, which was seen as in sharp contrast with the existing family value of hard work.

\section{Stage 1: Start-up and Establishment (1970-1993)}

Prior to establishing the company, the founder Einari Vidgrén earned his living in the woods as a logger. When machines replaced horses, Einari's risk-taking attitude and opportunity recognition led him to be among the first to adopt new and more efficient ways of working. However, Einari was unhappy with their reliability - they often broke down, impacting his income-so hedecided to solve the problem by building a better machine himself. The new machine was of higher quality, arousing interest in the market, and ultimately leading to the firm's establishment and building of a production facility in Vieremä.

Challenging the community-embedded family value. From the beginning, Einari's goal was to make 'the best machine in the business'. To many locals, the ambitious goal was perceived to be mismatched with the surroundings. At that time, social class distinctions in Finland were evident, and people living in the countryside were perceived as a lower social class. Although the shift toward a more equal social structure had begun, the culturally-embedded sense of geographic and social 
periphery influenced rural people's perceptions of theirself-worth, capabilities, and power (Aatsinki, 2009; History of Vieremä, 1983). Moreover, their experiences and memories of extreme poverty some decades earlier and the established frugal lifestyle emphasizing individual humility constituted an obvious mismatch. Thus, as Einari introduced the business value to be the best in the business, the prevailing value of humbleness (denoting lower social rank and low self-esteem) was challenged. His son explained the perceived contrast between the environment and the founder's future aspirations:

Finland in the 1970s was miserable, if you went to the countryside it looked miserable [...] At this point, Einari said that we need to make a Mercedes-Benz of the forest machines. And that sounded like a joke; how could you do it because in the 1970s Mercedes-Benzwas world-class. But saying that he made a new rule, we had to do it. (Interview, Owner and Chairman of the Board)

The locals did not believe that a company from a small rural village could challenge large, world class competitors. The retired Vieremä municipal manager recalled that even establishing the production facility was challenged and contested by the local council:

Einari needed a factory and approached the Vieremä municipality a sking them to build a factory for him to rent. The vote in Einari's favour was very tight: the council was divided, many thought that a forest machine factory in a place like Vieremä could never succeed [...] The supporters defeated the opponents by only one vote. (Interview, retired Municipal Manager)

For Einari, who grew up in Vieremä, the traditional local value system was a central and distinctive reference point for his thinking and acting in business. Analysing evidence from various data sources, we found that valuessuch as hardwork, equality, and humbleness (denoting the quality of not being proud) guided him in all his activities. Other informants also emphasized that living in a small agricultural village where farming was the main source of income meant that working diligently was the only way to survive. The founder's son referred to it as a Lutheran working mentality, where hard work was valued the most.

Even though Einari was head of the company, he always emphasized equality and the importance of working together, just as working in farms would naturally entail. This meant that everyone was supposed to put their fair share of work into the company, but also that no one was perceived better 
than anyone else. In Einari's words: "Everyone is expected to participate in the development and work equally hard" (History of Ponsse, 2007). Denoting humbleness, no one, including Einari, was given special status or privileges. Einari did not want to be referred to as a boss. The first external (i.e., non-local) employee recalled Einari's response when addressing him too formally: "we are all in this same house - I am Einari”.

Espousing industry-embedded business values. While Einari continued to implicitly emphasise the founding family values (hard work, equality, and humbleness), he also introduced and insisted on the new business values, which he considered pivotal to the company's success and growth. He introduced a new, business-centric set of guiding values (focus on high quality, innovation, customer centricity), and practicing these values he 'walked the talk', creating awareness and emulation.

Innovation in product development was initially driven by the founder who was not afraid to do things differently. As a result, the firm was constantly on the crest of a wave, above and beyond its competitors in introducing new high-quality products or features to the market. For example, responding to the awakening of the environmental movement in the 1980s, Einari came up with the idea of using aluminium to decrease the weight. "The competitors couldn't believe it" remembered Ponsse's first employee, as the machine outperformed all its competitors. Their proactiveness shaped the industry's future, and environmental friendliness became a design cornerstone, with Ponsse as the forerunner. Customer centricity was emphasized by keeping close relations with customers. For example, the founder would often drive thousands of kilometres to visit customers. Understanding customer needs and concerns was considered critical in product development and innovation. As the founder highlighted:

This is cooperation. Everyone participates in the development and the end users are the critical loop. (Einari Vidgrén, History of Ponsse, 2007)

Envisioning the future. Despite his modest background, Einari had strong faith in the future. Ponsse's first employee recalled that as the company did not have a brand in the early days, many were suspicions of its' possibility to succeed. The perceived imbalance and the consequent distrust 
in the firm's possibilities were evident, for example, in the difficulty in obtaining financing from the local bank. However, as Ponsse's first employee recalled, Einari never gave up. The data suggest that the founder's perseverance and 'strong nerves' helped them through the financial struggles in the early years. As the founder later recalled:

I had to wait every morning in front of the bank manager's door to negotiate for loans [...] When we started, we did not have the current 'brand', and there was a lot of suspicion. (Einari Vidgrén, History of Ponsse, 2007)

In 1971, when the first qualified engineer came for a job interview, he too was doubtful of the firm's prospects. However, it was the founder's optimism and strong faith in the future that ultimately convinced him to take the job.

The leader [Einari] came in and spoke with a strong Savo (regional) dialect. Understanding the dialect was difficult, but his optimism, strong faith in the future, and talk about how strong the machines that they had already built were, dispelled any doubts. (Interview, the first Engineer)

Thus, regardless of the initial disbelief of the local community and other key stakeholders, the founder was able to arouse interest and convince people through his own personal characteristics and behaviour. The initial observations resonate with prior research emphasizing the role of family founders and their resources as pivotal in the family firm founding stage (e.g., Littunen and Hyrsky, 2000; Steier, 2007). He was persuasive and credible, as he appeared honest, easy to understand, had a strong sense of direction, and was hard working. According to the retired municipality manager, the decision to support building the factory was sustained by these qualities; they knew his background and his work mentality. In addition to having shown his diligence, his credibility was increased by the fact that he was one of them, i.e., he came from the village.

Outcome: Temporary dominance of business values enabling early entrepreneurial growth. Our data suggest that the founder's characteristics and communication skills stimulated entrepreneurial behaviour and even a risk-taking attitude among employees. The founder's motivational ability enabled employees and those close to him to see the opportunities by engaging them as a critical resource to drive growth. The interview records show that employees were willing to work long days, sometimes even spending the night at the factory sleeping on the floor. During 
the difficult times, they were even willing to share some financial risks by participating in the purchasing of important components. As the first employee recalled:

Einari never gave up. And we had all kinds of challenges and setbacks. Many times, we had to empty both of our pockets to buy spare parts and stuff for the machines. Youneeded strong nerves, many people would have quit. (Interview, Ponsse's first employee)

Although initially the locals did not believe in the company's potential or survival, and the founder had to promote the business value to be the best in the business over the locally rooted humbleness value, as Ponsse began to gain in reputation, the local community started to believe in the newly-added business values and bold goals. In 1985, fifteen years after the company's foundation, the local newspaper announced that "Ponsse had performed a small miracle" by positioning the company as a forerunner of technological innovations in the field. The successes, which could now be measured in financial, reputational, and growth terms, infused the local community with an arousing sense of pride and self-confidence. The villagers' collective thoughts were expressed in a local newspaper article:

Ponsse is not the biggest or the most beautiful, but it certainly makes the best machines (Newspaper article, Miilu, 1985)

\section{Stage 2: International Expansion and Professionalization (1994-2009)}

By 1988, Ponsse had established a strong position in the Finnish market. The company sought to grow and gain more market share, but did not wish to start a fierce price competition in Finland. The only option was to enter new markets abroad, and in 1994 the firm established its first foreign subsidiary in Sweden. By this time, the hunger for business success and growth had also infused the employees:

The spirit of the company and success started growing substantially in 1994. In those years, we had a strong desire to succeed and show everyone. We were a small company in the market and almost always the underdog. But we wanted to succeed, become better, and be the best. (Interview, Product Manager)

Later that year, Einari's brother - Ponsse's first CEO - passed away. To fill the vast gap in management and secure the ongoing growth and expansion, the company looked for a highly qualified successor from the industry with a strong track record in managing growth and 
internationalization. The first non-family CEO was hired, and internationalization proceeded rapidly with Ponsse establishing subsidiaries in the US, France, and Great Britain in 1995. Ten years later, led by another non-family-CEO, expansion continued with subsidiaries in Russia, South America, and South Africa. By 2005, foreign sales had reached 65\% (Ponsse Financial Report, 2006). The rapid internationalization was noted by the media, but also in the village, due to the increasing number of foreign visitors. Ponsse's CEO at the time highlighted their competitiveness, growth and positive outlook:

During the year, Ponsse's business operations developed. Development occurred despite the fact that the worldwide market did not grow. We succeeded in increasing our market share both domestically and globally. Our order books began to rise in the last quarter, increasing by $22 \%$ on the previous year. (Ponsse Financial Statement, 2006)

At this time, the business values were noticeably visible. Ponsse consolidated its reputation for high-quality, innovative products, and close customer relations (History of Ponsse, 2007). The innovations and success led to awards and recognition on a national level. For example, in 2001 the Finnish Forestry Association awarded Einari Vidgrén for his entrepreneurship in creating one of the world's most successful companies manufacturing harvesting machines. In 2003, the firm received the Fennia Prize for forward-looking design.

Rejecting external business values. Based on the financial results, it is clear that the non-family CEOs had succeeded in upholding the firm's business values, while also strengthening international growth. In this respect, the company had succeeded in finding the right successors. However, despite the fact that the firm was indisputably meeting its business goals, and even exceeding them, the founder was not satisfied with the new top management. His son explained that the biggest problem was that Einari was unable to trust them:

The death of my father's brother (the first CEO) was the most critical event [...] It happened fast; he had a heart attack. The next day they had to choose the new CEO. The guy was good, but he couldn't keep the relationship with Einari so open [...] He started to suspecteverything. What kinds ofdeals we were making-even though the company was at its best in '97 and '98 iflooking at profitability. We were growing very fast. (Interview, Owner and Chairman of the Board)

Although the non-family CEOs were competent and successful in meeting the business goals, the 
other fundamental values and norms were not met. This misalignment of values was also perceived by the employees. According to our informants, the main problem was the sense of inequality they experienced with the new CEOs due to the introduction of hierarchical leadership. In other words, the CEOs did not fit well with the traditional family value of equality. Einari had always emphasized and enacted both the family and the business values. When the non-family CEOs did not act on equality, it created feelings of distrust in the entire organization. As one employee explained:

Some of the CEOs (non-family) thought that they were somehow better than the rest of us. If you think like that you have to go. Mutual respect and trust between the management and employees is what the Ponsse spirit is all about. (Interview, Supervisor)

Espousing family values. In this stage, the non-family CEOs' adherence to the hierarchical leadership value was in sharp contrast with Einari's behaviour. Whereas Einari was very close to employees and their families, the non-family CEOs kept their distance from the workers and the local community. Einari's openness and ties to the people were perceivable in many ways; he was described as a family-oriented man who knew the families in the village very well. There was no perception of superiority, he was like anybody else in the village. As one employee remarked:

I think everything here relates to the fact that we are all equal. They (the founder and the sons) take into account even the youngest employee. In many places, leaders are faceless but here you can see them at the coffee table, in the factory, talking with everyone. They actively participate in leisure activities. In many other places, the leaders set themselves much higher, don't lower themselves to the workers' level. But here we are all at the same level. (Interview, Supervisor)

A concrete example of showing and emphasizing equality was when the founder bought a new car. The car was expensive and he wanted the people's blessing. At this time, Einari was already a very wealthy man but did not want to show off and was worried about the villagers' reactions. An informant recalled how Einari asked the receptionists at the factory whether he should buy such an expensive car. Reportedly, their answer was unanimous: "Go ahead, you have eamed it".

To revitalize the family values, the founder strengthened the family presence in the firm. Hecalled back his second oldest son to join the company, despite the fact that he did not have vocational training or experience in forest machinery. He had worked as an elementary school teacher until 1998 when he started in public relations at Ponsse. Although he did not have engineering or 
international business competencies, he and Einari were similar in other ways, especially in their love for Vieremä. The informants described the son as a 'true Vieremä-man' who shared his father's interest and passion for the village and local way of living. Vieremä was and is an intrinsic part of his character, and the decision to quit his teaching job and return to the village to work for the company was 'easy', empowered partly by the sense of obligation to the firm. As he recalled:

I came to work in 1998. One of the reasons was that Einari couldn't trust the people around him. That's what he said to me [...] At the time when I came to work, my other brothers were working abroad. He needed to have one close to him. That's my case. (Interview, Owner and Chairman of the Board)

Screening the past and the future. Einari learned about the locals' past experiences and future expectations by carefully listening to them. His closeness to the local people enabled the villagers to express their concerns and opinions to him easily and frequently. Einari was an active member of the community and often participated in local events and happenings, where people could easily approach him. His son also recalled how the locals would call him at all times on various matters, and he always answered their calls and listened to their concerns and questions. As one employee observed:

Einari listened very carefully to what people were saying. Of course, he could recognize truth or falsehoods [...] In this period, there were a lot of changes in the organization. A lot of instability [...] I think Einaribelieved in people [...] He listened to people's opinions a lot. (Interview, HR manager)

While being attentive to local people's concerns, the data suggest that he also collected information by exploring peoples' perceptions about the firm and its employees. Being close to people and open to their views allowed Einari to hear various voices and opinions, informing his decision-making.

Outcome: Rebalancing family and business values enabling locally rooted international entrepreneurship. Although the non-family CEOs brought financial success, they were, without exception, fired because they imposed hierarchical leadership. As a result, the company changed its CEO four times between 1994 and 2008. As his son recalled:

In 2000, we changed CEO, in 2001 we changed CEO, in 2004 and in 2008 again we changed 
CEO. When we changed CEOs did we, did they do wrong or right? It wasn't a matter of that, it was a matter of trust and how Einari couldn't feel it with those people. And sometimes losing trust, just small things matter. (Interview, Owner and Chairman of the Board)

After this extended period of time, characterized by heightened conflicts between the family and business values, in 2008, Ponsse's production manager was appointed as the new CEO. Besides being recognized as a humble, easy-going, and village-like person, he also had a proven record of excellent people management skills at the factory. People knew him, and coming from within, he was someone they could trust. According to one informant: "He fits in well because he shares the Ponsse and the village values - even if he comes from another city". He had grown in the company and was acculturated to the family values. The late owner evaluated the choice as follows:

The appointment meets the expectations we have for the new President and CEO, says Einari Vidgrén, Chairman of the Board of Director. (Ponsse Press Release, 20.3.2008)

Clearly, at this point the hierarchical leadership value was eradicated, and the equality value prioritized. This values work created a generalized feeling of empowerment among employees, thanks to more trustful relationships with the top management, and thus a stronger and more coordinated entrepreneurial effort (e.g., Hornsby et al., 1999). At the same time, the values work performed by the family business leaders strengthened the relationships between the family firm and the local community.

\section{Stage 3: Maturity (2010-2017)}

Einari Vidgrén, the founder and Chairman of the Board of Directors, passed away suddenly at the age of 67 on 26 October 2010. His death was a sad news for his family, employees, and the locals. Many people were worried and wondered what would happen to Ponsse and Vieremä. This, in turn, shif ted the attention of Ponsse toward a new strategic priority: to ensure the continuity and growth of the family business beyond the founding generation (Jaskiewicz et al., 2015; Zellweger and Sieger, 2012).

The Board of Directors were soon reorganized and one of his sons was unanimously elected as the new Chairman. The other three sons continued in their managerial roles and the family remained 
the company's main shareholder. Although the business was running as smoothly as before, their father's death raised significant concerns about the continuity of family firm values. The death of the founder, the 'incarnation of the values', left a void, which meant that they could no longer consult him in taking the right decisions. Thus, the sons felt the need to make core values more visible to everyone. This is highlighted also in the company's website:

The values and operating methods set up by Einari Vidgrén for Ponsse lay a strong foundation and a firm set of values for the company's operations, also in the future (www.ponsse.fi)

Normalizing business values. At the third stage, high quality, innovativeness, customercentricity, and to be the best in the business had become routinized and taken forgranted. On its website, Ponsse is described as 'a logger's best friend', a company that develops and manufactures sustainable and innovative harvesting solutions based on customer needs. Its position as a global leader in timberharvesting solutions is solid. The company asserts that its' machines are famous for being the best forest machines in the world, exactly as desired and designed from the beginning. The employees are also well aware of and accustomed to the company's highly esteemed position and reputation in the global market. As one informant proudly remarked:

We used to be a small machine manufacturer but now we are so much bigger. We have all the latest technology and equipment in the factory. Our product is wanted all around the world. We have created a well-known brand. We are almost a legend! (Interview, Supervisor)

A clear indication of the company's continued capacity to innovate was the launch of a new flagship product in 2013. The launch started a complete modernization, with a focus on improved productivity, ergonomics and serviceability. Again, the new product was designed based on customer needs: efficiency, durability, and ease of use. The employees strongly believe that the genuine interest in customers and fulfilling their needs has greatly facilitated the company's continuous growth. In addition, as a recognition of their long-term achievements, Ponsse won the Finnish 2013 Family Business of the Year Award, commending the successful transfer to the next generation as evidenced by the doubled turnover over the six subsequent years.

Materializing family values. While the business values had become routinized, the 
intergenerational continuation of the family values was perceived at risk. This was due to the wake of the new societal trends visible especially among younger generation. The municipality had transformed from an agrarian society into a modern industrial society, which resulted in the deterioration of the traits and work culture emanating from the farms. The old family values, such as hard work, were no longer self-evident to the municipality's youth, and so to the employees. As the founder's son lamented:

I think the biggest stress nowadays foryoung people is: 'I havelostmy iPhone charger. My phone is dead. I cannot do anything '. My grandmother's biggest stress was that she had seven children and five cows. She needed to heat the cattle room every morning when it was $-35^{\circ}$ and milk the cows when her husband was in the forestry. The level of stress was on a 1,000 kind of scale. And we have lost that. (Interview, Owner and Chairman of the Board)

The owner's concerns were related to peoples' ability to work under stress, their willingness to push themselves, and their capability and interest to accomplish varioustasks. He felt that hard work, a core value in the family firm's history, was at risk by the growing individualism and appreciation of easy living embraced by the younger generation. In fear of losing an important component of the firm's past success, the firm's main challenge became to transmit the work attitudes and values to the next generation of workers.

As a first step to combat the societal change, the brothers defined the values more concretely and wrote them down. Hard work was emphasized as foundational to the company's success and traced back to Einari's childhood. As one of the sons explained:

Ponsse's organizational values came from my father's childhood. My grandfather went to war. My grandmother had to raise many children alone, while working the whole day on the farm. God will not provide for the lazyones [...] This is the root of the value of working hard (Interview, Owner and Chairman of the Board)

The values were reinforced in different ways, but generally linked to the founder and to the stories from the company's early days. Posters with pictures and the founder's old sayings were collected and put on display. To emphasise the core value of hard work, one of the sons even reconstructed Einari's childhood home to show how simple and hard life was back then. Through this, he transmitted the message that people were able to survive and succeed only through having a diligent 
work attitude.

Embodying past values. The intergenerational continuation of the family values was also safeguarded by the second-generation sons embodying and acting upon them. For example, the sons did not want to appear as millionaires but maintained a low profile. One of the sons explained:

You don't see any jet set here. [...] I have been raised in such a way that I work and do things as I wouldn't have any money. I think that makes things easier for me. (Juha Vidgren, Yle News 2017)

Supposedly, assimilating to the local way of living prompted their own motivation for working hard, while also showing example and dedication to work to others. Indeed, many informants felt that the sons' impact on the continuous existence and permanence of the company's spirit wascentral.

One employee commented:

Everything starts with the Ponsse spirit that Einaricreated. It has not changed. The boys have managed to keep it well. They [sons] are all top people. They are not proud; they sit together with the workmen. The company is only getting better. (Interview, first employee)

While all the sons participated in the enactment of the family values through their own roles, the impact of the new Chairman of the Board was most pervasive. A general perception among the informants was that he had successfully taken Einari's place. One local villager pointed out:

For him [the son], what happens in the village is very important. In other words, the attitude of caring for 'normal' people has not changed. I don't know the detailed systems of the firm that have changed, but this is what I thinkconnects the pastand present generations. (Interview, Local residentC)

Although Einari actively participated in local events, it seems that his son valued Ponsse's connection with Vieremä even more, taking a proactive role in driving different projects, improvements, and organizing events for the locals. A special attention has been given to organizing various events for youth (e.g. summer work camps, cultivation courses) in order to revive their interest and respect for work. The owner pointed out:

I think the best way to explain the values is to tell where they are coming - from the family of Einari. Why there is a respect for work, why there is a respect of all kinds of work. And that all kind of work is important and every people who work are also equal. (Interview, Owner and Chairman of the Board) 
family firm. During the field work, we noticed that the second generation's efforts to materialize and embody the past values allowed Einari's and Ponsse's values to be acknowledged and appreciated among the people. Spreading the collective values and especially the value of hard work throughout the organization has been important for the family firm to maintain an entrepreneurial attitude in a stage of business maturity (e.g., Jaskiewicz et al.,2015). For example, the Chairman madereferences to the past family values that resonated with the values of their historical suppliers and customers, and helped the family firm engage in entrepreneurial adaptation to renew past competitive advantages (e.g., Covin and Miles, 2006). The interviews with the local business partners show that they considered themselves part of the "Ponsse family, sharing the common values". The stories had also resonated with the people displaying feelings of gratitude to the past generation as fundamental to the firm's existence and success. As an informant highlighted:

Sometimes it is good to be reminded of all the sacrifices that the people whocreated this company for us had to make in those days. Maybe then we wouldn't selfishly demand all the benefits that we sometimes do. (Interview, Product Manager)

In sum, spreading the family values to wider stakeholders was critical to rebalance conflicting values and ensure that the firm's culture would continue to fuel entrepreneurial behaviour during the maturity stage.

\section{Theory Building: System-Spanning Values Work as Driver of Corporate Entrepreneurship in Family Firms}

Previous research suggests that value tensions put major threats to the family firm's ability to engage in corporate entrepreneurship and growth over time. Our findings reveal that, to manage and resolve these tensions, family business leaders engaged in a particular form of values work through which they invoked specific values to address the emerging concerns of key stakeholders (Gehman et al., 2013). Interestingly, they did so by acting on values across the family system and the business system, as well as across different temporal orientations. These observations led us to introduce the concept of system-spanning values work, a particular type of values work that appeared particularly suitable to explain how family firms address value tensions over time. 
In the start-up stage, system-spanning values work included challenging the locally rooted family value, while espousing (Schein, 1985) a business value. Through espousing the new business value, the family firm leader envisioned the future, thereby attaching future orientation to the value (Bourne and Jenkins, 2013). Collectively, we label the sum of these activities as 'rooting', as it installs a new business value into the locally rooted family system, forming the initial 'family business sy stem' (Kepner, 1983; Olson et al., 2003; Michael-Tsabari, Labaki and Zachary, 2014). Contrary to earlier findings (Aldrich and Cliff, 2003; Rogoff and Heck, 2003), 'rooting' highlights the importance of introducing business values in the family firm's early stage of development. But also shows that doing so inevitably leads to a temporary downplay of certain family values (in our case, humbleness), to infuse entrepreneurial ambition into the business.

In the international expansion stage, system-spanning values work comprised of the espousal of the family values and rejection of an unwelcome external business value. Our analysis shows that this involved careful screening of past experiences and future expectations among stakeholders. Collectively, the interplay of these mechanisms gave rise to a type of values work that we label 'revitalizing' insofar as it re-balances the family and business values in the firm. Counterintuitively, our analysis highlights that even in the context of aggressive risk-taking that characterizes international entrepreneurship (Zahra, 2003), the family firm can defend the family values and strengthen kinship with the local community, thereby breaking the often-observed tension between the preservation of family values and entrepreneurial expansion.

Finally, in the maturity stage, the family values were materialized while the business values were normalized. Materialization translates the espoused values into an artefactual form (Schein, 1985) to prevent the drift of family values and the emergence of unwelcome values (i.e., individualism). In contrast, normalization refers to the routinization of values in the organizational structures and systems. The family business leader also directed the attention to the 'past', making an effort to inherit and embody values from the previous generation. Collectively, welabel the sum of this values work as 'spreading' insofar as this is helps the family business approach the maturity stage by 
leveraging family tradition and legacy to ensure cross-generational entrepreneurial behaviour (Jaskiewicz et al., 2015; Minola et al., 2016; Zellweger and Sieger, 2012). Compared to earlier findings (e.g., Hjorth and Dawson, 2016; Jaskiewicz et al., 2015), our analysis highlights the importance of materializing and embodying specifically selected family values to maintain meaningful link to the past, thereby encouraging continued entrepreneurial behaviour in a mature family firm.

\section{DISCUSSION}

\section{Contributions to the Literature}

Our longitudinal study is the first to track the micro-level evolution of family business values throughout the entrepreneurial lifecycle of a family firm (Zahra, 2018). This provides a rare opportunity to advance knowledge on the role of culture and values for corporate entrepreneurship in family firms (Michael-Tsabari et al., 2014; Minola et al., 2016;Zahra and Filatotchev, 2004), as well as inform more generally current understanding about values and culture in family business literature (e.g., Hall et al., 2001; Parada et al., 2010) and management and organization studies (Gehman et al., 2013).

First, our study contributes new insights concerning the effects of family firm's culture and values on corporate entrepreneurship. In this literature, several scholars have argued that family firms' distinctive culture and values initially fuel entrepreneurship, but tend to become a burden in later stages of their development (e.g., De Massis et al., 2013; Jaskiewicz et al., 2015; Reay et al., 2015; Zellweger and Sieger, 2012). Likewise, quantitative studies have yielded mixed results concerning whether family values become more or less prominent over time (e.g., Zellweger et al., 2012), and whether they enable or constrain entrepreneurial behaviour in family firms (e.g., Reay et al., 2015). Our study helps reconcile conflicting views showing that the balance between family and business values changes dynamically and that those dynamics matter for sustaining entrepreneurship in family firms over time. Specifically, the concept of system-spanning values work contributes to this literature by conceptualizing family business leaders' efforts in resolving value tensions as an 
important micro-foundation (e.g., De Massis and Foss, 2018) that helps explain the previously observed heterogeneity in corporate entrepreneurship among family firms (Eddleston et al., 2012; Kellermanns and Eddleston, 2006; Zahra et al., 2004).

Specifically, the micro-foundations perspective advanced in this study helps explain how, in the early stages of a family firm's development, family business leaders may engage in rooting to introduce new business values while temporarily downplaying certain family values, thereby envisioning the future and infusing an entrepreneurial ambition into the business. Also, our analysis suggests that, later in a family firm's development, family business leaders can reject external business values and place a renewed emphasis on pastfamily values, thereby revitalizing the firm's original entrepreneurial outlook. Finally, in the maturity stage, materializing family values while normalizing business values can be instrumental to spreading the values underpinning the family tradition and legacy, thereby avoiding conservatism and boosting entrepreneurial behaviour (e.g., Jaskiewicz et al., 2015). In sum, explicating the family, business and temporal mechanisms underlying system-spanning values work paves the way for a more nuanced and dynamic understanding of how values embedded in the family and the business systems interact in influencing family firm' entrepreneurial behaviour(Jaskiewicz et al., 2015; Reay et al., 2015).

The second contribution of our study relates to research on family firm culture, which has so far been conceptualized and studied at the firm level of analysis (e.g., Hall et al., 2001; Parada et al., 2010). Previous research has relied on broader concepts such as institutional logics to examine the diffusion of internally coherent or systematic sets of values in family firms (e.g., Hall et al., 2001; Parada et al., 2010; Reay et al., 2015). Also, scholars have argued that family firm culture originates from the personal values of the founder and other family members (Zwack et al., 2016), as well as from the surrounding environment (Miller and Le Breton-Miller, 2005; Parada et al., 2010). Some scholars have started to disclose the heterogeneity of values across family firms, identifying a taxonomy of family firm value profiles (Rau, Schneider-Siebke and Günther, 2019) or recurrent value configurations (Koiranen, 2002). While this body of research acknowledges the complex 
nature of values in family firms, our study makes a step forward in suggesting that values are tools that can be used to solve problems and construct strategies as a family firm grows and develops.

More precisely, our study shows the values practices and related mechanisms through which family firms' overarching culture can be dynamically shaped by the local community and broader industry in which they are embedded, creating a multiplicity of values that are more/less prominent over time. We suggest family business research should take value interactions seriously, viewing the family system, the business systems, as well as the local community and industry as sources of a cultural tool kit (Swidler, 1986; Weber, 2005) available to family firms. Applying the tool kit perspective of values to family business system theory is beneficial, as it enables unpacking the family business system as "variable in time and space"(Weber, 2005,p. 229) where the use of values is constrained by the actors' cognitive and social limitations. In this regard, our findings complement and extend previous research efforts thathave addressed the social interactions through which values and goals are negotiated (e.g., Kammerlander and Ganter, 2015; Kotlar and De Massis, 2013), and how historic values are handed down and strategically used across generations (Sasaki et al., 2019).

Finally, our study holds important implications for the broader literature on values work in management and organization studies, where values have traditionally been conceptualised as webs of meanings that guide and constrain organizational behaviour (Schein, 1990). More recently, a growing interest has been paid to questions concerning how values emerge, become recognized, are repeatedly performed and contested among actors (Gehman et al., 2013; Wright et al., 2017; 2020). These studies conceptualize values as formed and continuously renegotiated by the surrounding communities (Daskalaki et al., 2015), and actively intervening in situations, and creating and reworking tensions over time (Gehman et al., 2013). We add to this literature by focusing on the dynamics of values in the context of a multi-system family business. Contrary to earlier studies that suggest the enrichment of the repertoire of values from the surrounding community for strategy making (e.g., Rindova, Dalpiaz and Ravasi, 2011), our study shows that while in the formation stage the enrichment strategy makes sense to establish the family business system in the first place, in the 
long run, limiting the repertoire of values is important to maintain cohesion of the family bu siness system. This finding is important because it shows that family firms may cope better with change when using narrower repertoire of values. Moreover, our research highlights the role of temporal work in providing an intended temporal direction to actions (Kunisch et al., 2017), determining the future strategic course. While temporal orientation has not been explicitly theorised as a key mechanism in past values work studies (except the conceptual analysis presented by Bourne and Jenkin, 2013), our study highlights its central role in setting the 'strategic directionality of the values work'. We argue that as using values from the various internal and external cultural registers(Weber, 2005, p. 229) is difficult, costly, and potentially detrimental to organizations (Rindova et al., 2011), leaders need to provide cognitive directionality to their values work through the use of the temporal mechanism. Overall, the idea that values work enfolds across multiple organizational sub-systems and across time provides fertile ground for future research exploring how culture drives corporate entrepreneurship in different types of companies (e.g., Morris and Schindehutte, 2005).

\section{Managerial Implications}

Our study suggests family business leaders to use culture and values as key resources to drive corporate entrepreneurship and growth. Our study shows that tensions between family and business values are likely to arise as the family firm develops and may slow a family firm's initial entrepreneurial momentum. Our study provides family business leaders with valuable insights on how they can effectively address such tensions, preventing a possible cultural breakdown, and instead leveraging value tensions to continuously emphasise entrepreneurship and growth. In this regard, our emphasis on system-spanning values work - comprising the family, business, and temporal mechanisms - provides owners and managers with several opportunities to actively manage the family firm. In sum, through rooting, revitalizing, and spreading family and business values, family firms can enhance the possibility of sustaining corporate entrepreneurship over an extended period of time.

\section{Limitations and Future Research}


First, as for all qualitative case studies, the empirical generalizability of our findings is limited to the specific firm we studied. Yet, while our findings are context-specific in terms of the values mobilized over time, the three stages of the family firm's development we observed are typical of wider population family firms, and the system-spanning values work concept derived may hence be theoretically generalizable (Yin, 2009). Similarly, our theoretical insights concerning the multiple mechanisms of values work (family, business, and temporal mechanisms) may be generalizable to other family firms that continue to maintain strong local embeddedness despite sustained entrepreneurial growth. Exploring variations of values work across family firms and ensuing boundary conditions of our theoretical conclusions represent fruitful avenues for future research.

Second, our study focused primarily on the family firm's internal value system and its entrepreneurial behaviour. Hence, our observations about how these practices shaped externalvalues systems such as the industry or the community are inherently limited. More systematic investigation of the external outcomes of values work, however, is a promising direction for future research (e.g., Parada et al., 2010).

Finally, although we employed data collection techniques that facilitate the accuracy of informants' remembrances, and used additional data to triangulate our main evidence, our longitudinal case study analysis ultimately relies on the oral memories of our informants, hence residual biases may have influenced our theorizing. Notwithstanding its inherent limitations, our study highlights the value of combining archival evidence (to retrieve key events) and retrospective interviews (to understand the meanings and interpretations of events) in order to study phenomena that enfold overan extended period of time, and to appreciate the links between intangible constructs, such as culture and values, and more concrete aspects of firm behaviour and performance. Thus, our study can provide researchers with valuable methodological insights for reconstructing informants' memories and minimizing biases in future research.

\section{CONCLUSIONS}

Our study shows that values work plays an important role to sustain corporate entrepreneurship in 
family firms over an extended period of time. Showing how values work is articulated through family, business, and temporal mechanisms, and showing how distinct types of values work help family business leaders foster entrepreneurial growth across a family firm's life-cycle enriches current understanding of the dynamics of value conflicts in family firms, as well as their effects on corporate entrepreneurship over time.

\section{NOTES}

[1] Conceptualizations of organizational culture vary across the literature (Giorgi et al. 2015). In this paper, we follow the long-standing view in organization studies that values constitute the microfoundations of organizational culture (e.g., Giorgi et al., 2015). This literature acknowledges the coexistence of multiple values within an organization, which may at times be inconsistent or conflicting with one another (Giorgi et al., 2015).

[2] 'We' in the data analysis refers to the first and second author, who led the collection and analysis of the empirical data.

\section{REFERENCES}

Aatsinki, U. (2008). Tukkiliikkeestä Kommunismiin: Lapin Työväenliikkeen Radikalisoituminen Ennen Ja Jälkeen 1918. University of Tampere.

Aldrich, H. E. and Cliff, J. E. (2003). 'The pervasive effects of family on entrepreneurship: Toward a family embeddedness perspective'. Journal of Business Venturing, 18(5), 573-96.

Bennedsen, M. and Van der Heyden, L. (2010). 'When MBAs meet Henokiens: What can we learn from long-lived family firms?' Fontainebleau: INSEAD, Faculty \& Research Working Paper 2010/81/EPS/EFE/TOM/WICFE.

Bird, M. and Zellweger, T. (2018). 'Relational embeddedness and firm growth: Comparing spousal and sibling entrepreneurs'. Organization Science, 29(2), 264-83.

Bourne, H. and Jenkins, M. (2013). 'Organizational values: A dynamic perspective'. Organization Studies, 34(4), 495-514.

Chrisman, J. J. and Patel, P. C. (2012). 'Variations in R\&D investments of family and nonfamily firms: Behavioral agency and myopic loss aversion perspectives'. Academy of Management Journal, 55(4), 976-97.

Chua, J. H., Chrisman, J. J. and Chang, E. P. C. (2004). 'Are family firms born or made? An exploratory investigation'. Family Business Review, 17(1), 37-54.

Chua, J. H., Chrisman, J. J. and Sharma, P. (1999). 'Defining the family business by behavior'. Entrepreneurship Theory and Practice, 23(4), 19-39.

Covin, J. G., and Miles, M. P. (1999). 'Corporate entrepreneurship and the pursuit of competitive advantage'. Entrepreneurship theory and practice, 23(3), 47-63.

Cruz, C. and Nordqvist, M. (2012). 'Entrepreneurial orientation in family firms: A generational perspective'. Small Business Economics, 38(1), 33-49.

Daskalaki, M., Fotaki, M. and Sotiropoulou, I. (2018). 'Performing values practices and grassroots organizing: the case of solidarity economy initiatives in Greece'. Organization Studies, 40(11), $1741-65$.

Daskalaki, M., Hjorth, D. and Mair, J. (2015). 'Are entrepreneurship, communities, and social transformation related? Journal of Management Inquiry, 24(4), 419-23. 
De Massis, A., Chirico, F., Kotlar, J. and Naldi, L. (2013). 'The temporal evolution of proactiveness in family firms: The horizontal s-curve hypothesis'. Family Business Review, 27(1), 35-50.

De Massis, A. and Foss, N. J. (2018). 'Advancing family business research: The promise of microfoundations'. Family Business Review, 31(4), 386-96.

Dyer, W. G. (1986). Cultural Change in Family Firms: Anticipating and Managing Business and Family Transitions. San Francisco: Jossey-Bass.

Dyer, W. G. (1989). 'Integrating professional management into a family owned business'. Family Business Review, 2(3), 221-35.

Dyer, W. G. (2003). 'The family: The missing variable in organizational research'. Entrepreneurship Theory and Practice, 27(4), 401-16.

Eddleston, K. A., Kellermanns, F. W. and Zellweger, T. M. (2012). 'Exploring the entrepreneurial behavior of family firms: Does the stewardship perspective explain differences?' Entrepreneurship Theory and Practice, 36(2), 347-67.

Eisenhardt, K. M. and Graebner, M. E. (2007). 'Theory building from cases: Opportunities and challenges'. Academy of Management Journal, 50(1), 25-32.

Gehman, J., Treviño, L. K. and Garud, R. (2013). 'Values work: A process study of the emergence and performance of organizational values practices'. Academy of Management Journal, 56(1), 84-112.

Gersick, K. E., Davis, J. A., Hampton, M. M. and Lansberg, I. (1997). Generation to Generation: Life Cycles of the Family Business. Boston, MA: Harvard Business Press.

Giorgi, S., Lockwood, C. and Glynn, M. A. (2015). 'The many faces of culture: Making sense of 30 years of research on culture in organization studies'. Academy of Management Annals, 9(1), 154.

Gómez-Mejia, L. R., Makri, M. and Kintana, M. L. (2010). 'Diversification decisions in familycontrolled firms'. Journal of Management Studies, 47(2), 223-52.

Hall, A., Melin, L. and Nordqvist, M. (2001). 'Entrepreneurship as radical change in the family business: Exploring the role of cultural patterns'. Family Business Review, 14(3), 193-208.

Harvey, M. and Evans, R. E. (1994). 'Family business and multiple levels of conflict'. Family Business Review, 7(4), 331-48.

Hernes, T. (2014). A Process Theory of Organization. Oxford, UK: Oxford University Press.

Hinings, C. R., Thibault, L., Slack, T. and Kikulis, L. M. (1996). 'Values and organizational structure'. Human Relations, 49, 885-916.

Hjorth, D. and Dawson, A. (2016). 'The burden of history in the family business organization'. Organization Studies, 37(8), 1089-111.

Hornsby, J. S., Kuratko, D. F., and Montagno, R. V. (1999). 'Perception of internal factors for corporate entrepreneurship: A comparison of Canadian and US managers'. Entrepreneurship Theory and Practice, 24(2), 9-24.

Hoy, F. (2006). 'The complicating factor of life cycles in corporate venturing'. Entrepreneurship Theory and Practice, 30(6), 831-36.

Hoy, F. and Sharma, P. (2010). Entrepreneurial Family Firms. Upper Saddle River, NJ: Prentice Hall.

Jaskiewicz, P., Combs, J. G. and Rau, S. B. (2015). 'Entrepreneurial legacy: Toward a theory of how some family firms nurture transgenerational entrepreneurship'. Journal of Business Venturing, 30(1), 29-49.

Jaskiewicz, P., Heinrichs, K., Rau, S. B. and Reay, T. (2016). 'To be or not to be:How family firms manage family and commercial logics in succession'. Entrepreneurship Theory and Practice, 40(4), 781-813.

Kammerlander, N. and Ganter, M. (2015). 'An attention-based view of family firm adaptation to discontinuous technological change: Exploring the role of family CEOs' noneconomic goals'. Journal of Product Innovation Management, 32(3), 361-83. 
Kellermanns, F. W. and Eddleston, K. A. (2006). 'Corporate entrepreneurship in family firms: A family perspective'. Entrepreneurship Theory and Practice, 30(6), 809-30.

Kepner, E. (1983). 'The family and the firm: A co-evolutionary perspective'. Organizational Dynamics, 12(1), 57-70.

Koiranen, M. (2002). 'Over 100 years of age but still entrepreneurially active in business: Exploring the values and family characteristics of old Finnish family firms'. Family Business Review, 15(3), 175-87.

Kotlar, J. and De Massis, A. (2013). 'Goal setting in family firms: Goal diversity, social interactions, and collective commitment to family-centered goals'. Entrepreneurship Theory and Practice, 37(6), 1263-88.

Kunisch, S., Bartunek, J. M., Mueller, J. and Huy, Q. N. (2017). 'Time in strategic change research'. Academy of Management Annals, 11(2), 1005-64.

Langley, A. (1999). 'Strategies for theorizing from process data'. Academy of Management Review, 24(4), 691-710.

Le Breton-Miller, L. and Miller, D. (2013). 'Socioemotional wealth across the family firm life cycle: A commentary on "Family business survival and the role of boards"'. Entrepreneurship Theory and Practice, 37(6), 1391-97.

Lincoln, Y. S. and Guba, E. G. (1985). Naturalistic Inquiry. Newberry Park. CA: Sage.

Littunen, H. and Hyrsky, K. (2000). 'The early entrepreneurial stage in Finnish family and nonfamily firms'. Family Business Review, 13(1), 41-53.

Lumpkin, G. T. and Brigham, K. H. (2011). 'Long-term orientation and intertemporal choice in family firms'. Entrepreneurship Theory and Practice, 35(6), 1149-69.

Maclean, M., Harvey, C. and Clegg, S. R. (2016). 'Conceptualizing historical organization studies'. Academy of Management Review, 41(4), 609-32.

Maxwell, J. A. and Miller, B. A. (2008). 'Categorizing and connecting strategies in qualitative data analysis'. In Hesse-Biber, S. N. and Leavy, P. (Eds.), The Handbook of Emergent Methods. New York, NY: Guilford Press.

Mazzelli, A., Kotlar, J. and De Massis, A. (2018). 'Blending in while standing out: Selective conformity and new product introduction in family firms'. Entrepreneurship Theory and Practice, 42(2), 206-30.

Michael-Tsabari, N., Labaki, R. and Zachary, R. K. (2014). 'Toward the clu ster model: The family firm's entrepreneurial behavior over generations'. Family Business Review, 27(2), 161-85.

Miller, D. and Le Breton-Miller, I. (2005). Managing for the Long Run: Lessons in Competitive Advantage from Great Family Businesses. Harvard Business Press.

Miller, D., Le Breton-Miller, I. and Lester, R. H. (2013). 'Family firm governance, strategic conformity, and performance: Institutional vs. Strategic perspectives'. Organization Science, 24(1), 189-209.

Minola, T., Brumana, M., Campopiano, G., Garrett, R. P. and Cassia, L. (2016). 'Corporate venturing in family business: A developmental approach of the enterprising family'. Strategic Entrepreneurship Journal, 10(4), 395-412.

Morris, M., and Schindehutte, M. (2005). 'Entrepreneurial values and the ethnic enterprise: An examination of six subcultures'. Journal of Small Business Management, 43(4), 453-479.

Nordqvist, M. and Melin, L. (2010). 'Entrepreneurial families and family firms'. Entrepreneurship \& Regional Development, 22(3-4), 211-39.

Olson, P. D., Zuiker, V. S., Danes, S. M., Stafford, K., Heck, R. K. Z. and Duncan, K. A. (2003). 'The impact of the family and the bu siness on family business sustainability'. Journal of Business Venturing, 18(5), 639-66.

Parada, M. J. and Dawson, A. (2017). 'Building family business identity through transgenerational narratives. Journal of Organizational Change Management, 30(3), 344-56. 
Parada, M. J., Nordqvist, M. and Gimeno, A. (2010). 'Institutionalizing the family business: The role of professional associations in fostering a change of values'. Family Business Review, 23(4), 35572.

Pettigrew, A. M. (1990). 'Longitudinalfield research on change: Theory and practice'. Organization Science, 1(3), 267-92.

Rau, S. B., Schneider-Siebke, V. and Günther, C. (2019). 'Family firm valuesex plaining family firm heterogeneity'. Family Business Review, 32(2), 195-215.

Ravasi, D. (2017). 'Visualizing our way through theory building'. Journal of Management Inquiry, 26(2), 240-43.

Reay, T., Jaskiewicz, P. and Hinings, C. R. (2015). 'How family, business, and community logics shape family firm behavior and "rules of the game" in an organizational field'. Family Business Review, 28(4), 292-311.

Rindova, V., Dalpiaz, E. and Ravasi, D. (2011). 'A cultural quest: A study of organizational use of new cultural resources in strategy formation'. Organization Science, 22(2), 413-31.

Rogoff, E. G. and Heck, R. K. Z. (2003). 'Evolving research in entrepreneurship and family business: Recognizing family as the oxygen that feeds the fire of entrepreneurship'. Journal of Business Venturing, 18(5), 559-66.

Rubin, J. R. and Rubin, I. S. (2005). Qualitative Interviewing: The Art of Hearing Data. 2nd ed. Thousand Oaks, CA: Sage Publications.

Salvato, C., Chirico, F. and Sharma, P. (2010). 'Understanding exit from the founder's business in family firms'. In Stewart, A., Lumpkin, G. T. and Katz, J. A. (Eds.), Advances in Entrepreneurship, Firm Emergence, and Growth (vol. 12, pp. 31-85). Bingley, UK: Emerald Group Publishing.

Sasaki, I., Kotlar, J., Ravasi, D. and Vaara, E. (2019). 'Dealing with revered past: Historical identity statements and strategic change in Japanese family firms'. Strategic Management Journal (In press).

Sasaki, I., Ravasi, D. and Micelotta, E. (2019). 'Family firms as institutions: Cultural reproduction and status maintenance among multi-centenary shinise in Kyoto'. Organization Studies, 40(6), 793-831.

Schein, E. (1985). Organizational Culture and Leadership. San Francisco, CA: Jossey-Bass.

Schein, E. H. (1990). 'Organizational culture'. American Psychologist, 45(2), 109-19.

Schulze, W. S., Lubatkin, M. H. and Dino, R. N. (2003). 'Toward a theory of agency and altruism in family firms'. Journal of Business Venturing, 18(4), 473-90.

Siggelkow, N. (2007). 'Persuasion with case studies'. Academy of Management Journal, 50(1), 20 24.

Steier, L. (2007). 'New venture creation and organization: A familial sub-narrative'. Journal of Business Research, 60(10), 1099-107.

Stewart, A. and Hitt, M. A. (2012). 'Why can't a family business be more like a nonfamily business? Modes of professionalization in family firms'. Family Business Review, 25(1), 58-86.

Swidler, A. (1986). 'Culture in action: Symbols and strategies'. American Sociological Review, 51(2), 273-86.

Weber, K. (2005). 'A toolkit for analyzing corporate cultural toolkits. Poetics, 33(3-4), 227-52.

Wright, A. L., Irving, G., \& Selvan Thevatas, K. (2020). 'Professional Values and Managerialist Practices: Values work by nurses in the emergency department'. Organization Studies, in press.

Wright, A. L., Zammuto, R. F. and Liesch, P. W. (2017). 'Maintaining the values of a profession: Institutional work and moral emotions in the emergency department'. Academy of Management Journal, 60(1), 200-37.

Yin, R. K. (2009). Case Study Research: Design and Methods. Thousand Oaks, CA: Sage Publications.

Zachary, R. K. (2011). 'The importance of the family system in family business'. Journal of Family Business Management, 1(1), 26-36. 
Zahra, S. A. (2003). 'International expansion of US manufacturing family businesses: The effect of ownership and involvement'. Journal of Business Venturing, 18(4), 495-512.

Zahra, S. A. (2005). 'Entrepreneurial risk taking in family firms'. Family Business Review, 18(1), 23-40.

Zahra, S. A. (2018). 'Entrepreneurial risk taking in family firms: The wellspring of the regenerative capability'. Family Business Review, 31(2), 216-26.

Zahra, S. A. and Filatotchev, I. (2004). 'Governance of the entrepreneurial threshold firm: A knowledge based perspective'. Journal of Management Studies, 41(5), 885-97.

Zahra, S. A., Hayton, J. C. and Salvato, C. (2004). 'Entrepreneurship in family vs. non-family firms: A resource-based analysis of the effect of organizational culture'. Entrepreneurship Theory and Practice, 28(4), 363-81.

Zahra, S. A., Jennings, D. F., and Kuratko, D. F. (1999). 'The antecedents and consequences of firm-level entrepreneurship: The state of the field'. Entrepreneurship Theory and practice, 24(2), 45-65.

Zellweger, T. M., Kellermanns, F. W., Chrisman, J. J. and Chua, J. H. (2012). 'Family control and family firm valuation by family CEOs: The importance of intentions for transgenerational control'. Organization Science, 23(3), 851-68.

Zellweger, T. and Sieger, P. (2012). 'Entrepreneurial orientation in long-lived family firms'. Small Business Economics, 38(1), 67-84.

Zwack, M., Kraiczy, N. D., von Schlippe, A. and Hack, A. (2016). 'Storytelling and cultural family value transmission: Value perception of stories in family firms'. Management Learning, 47(5), 590-614. 
Table I. Summary of data sources

\begin{tabular}{|c|c|c|}
\hline Data type & The case firm & The local community \\
\hline Archives & $\begin{array}{l}\text { 1015 pages (excluding online and books): } \\
\text { Round 1: } \\
-\quad 1 \text { edited corporate history book (2007;89 } \\
\quad \text { pages) } \\
-\quad \text { Past speeches of Einari from 1983-2010 } \\
\quad \text { (10 pages) } \\
\text { - Company brochures (55 pages) } \\
\text { Round 2: } \\
-\quad 8 \text { a nnual reports from 1994-2018 (950 } \\
\quad \text { pages) } \\
\text { Round 3: } \\
-\quad 25 \text { online articles about Ponsse }\end{array}$ & $\begin{array}{l}\text { 78 pages (excluding online and books): } \\
\text { Round 1: } \\
\text { - } \quad \text { edited history book of Vieremä (1983, } \\
522 \text { pages) } \\
\text { Round 2: } \\
\quad 96 \text { relevant articles fromthe local } \\
\text { newspaper Miilu from } 1970-2016 \text { ( } 78 \\
\text { pages). The identification of articles } \\
\text { involved manual screening over } 20,800 \\
\text { pages of the local newspaper }\end{array}$ \\
\hline Interviews & $\begin{array}{l}\text { 34 interviews with 29 informants: } \\
\text { Round 1: Owner and Chairman of the Board (1 } \\
\text { interview), Ponsse'sfirst employee and Einari } \\
\text { Vigdrén's childhood friend (1), Supervisor and } \\
\text { son of the first employee (1) } \\
\text { Round 2: Owner and Chairman of the Board (2 } \\
\text { interviews), Ponsse's firstEngineer (1), } \\
\text { Marketing Assistant (1), HR Manager (1), } \\
\text { Public Relations Officer(1), Factory Tour } \\
\text { Guide (1), Partner (1), Account Manager from } \\
\text { Russia (1), Russian customers (7), Factory } \\
\text { Worker(1), Manager A(1), Manager B (1), } \\
\text { Product Manager (2) } \\
\text { Round 3: Owner and Chairman of the Board (2 } \\
\text { interviews), Swedish customers(2), Guests' } \\
\text { Hostess A(1), Guests' Hostess B (1), Ponsse } \\
\text { employees (4) }\end{array}$ & $\begin{array}{l}\text { 12 interviews with } 11 \text { informants: } \\
\text { Round 1: Municipality Manager, retired (1 } \\
\text { interview), Shopkeeper(1) } \\
\text { Round 2: Municipality Manager (1), Journalist } \\
\text { (1), Librarian (1) } \\
\text { At a local singing event: Local resident A (1), } \\
\text { Local resident B (1), Local resident C (1), } \\
\text { Local resident D, a woman who grew up in the } \\
\text { villa ge but lives abroad now (1) } \\
\text { At the children's playground: Local residentE } \\
\text { (1) } \\
\text { Round 3: Municipality Manager, retired (1), } \\
\text { Municipality officer (1) }\end{array}$ \\
\hline Observation & $\begin{array}{l}\text { Round 1: } 12-13.4 .2016 \text { (2 days) } \\
\text { Company presentation by the Owner \& } \\
\text { Chairman of the Board, visit to the restored } \\
\text { childhood home of Einari Vidgrén } \\
\text { Round 2: } 9-13.8 .2016 \text { ( } 5 \text { days) } \\
\text { Factory tour, event with the national Finnish } \\
\text { volleyball team at the factory (sponsored by } \\
\text { Ponsse), dinner with Russian customers a the } \\
\text { restored childhood home of Einari Vidgrén } \\
\text { Round 3: 28.8-1.9.2017 (5 days) } \\
\text { Dinner with Finnish customers, visit to } \\
\text { Vidgrén's stables }\end{array}$ & $\begin{array}{l}\text { Round 1: 12-13.4.2016 (2 days) } \\
\text { n.a. } \\
\text { Round } 2: 9-13.8 .2016 \text { ( } 5 \text { days) } \\
\text { Visit to the city council, interacting with the } \\
\text { locals in the city centre, children's playground, } \\
\text { local restaurants, gas station a nd local shops, a } \\
\text { local singing event } \\
\text { Round } 3: 28.8-1.9 .2017 \text { ( } 5 \text { days) } \\
\text { Visit to the local primary school }\end{array}$ \\
\hline
\end{tabular}




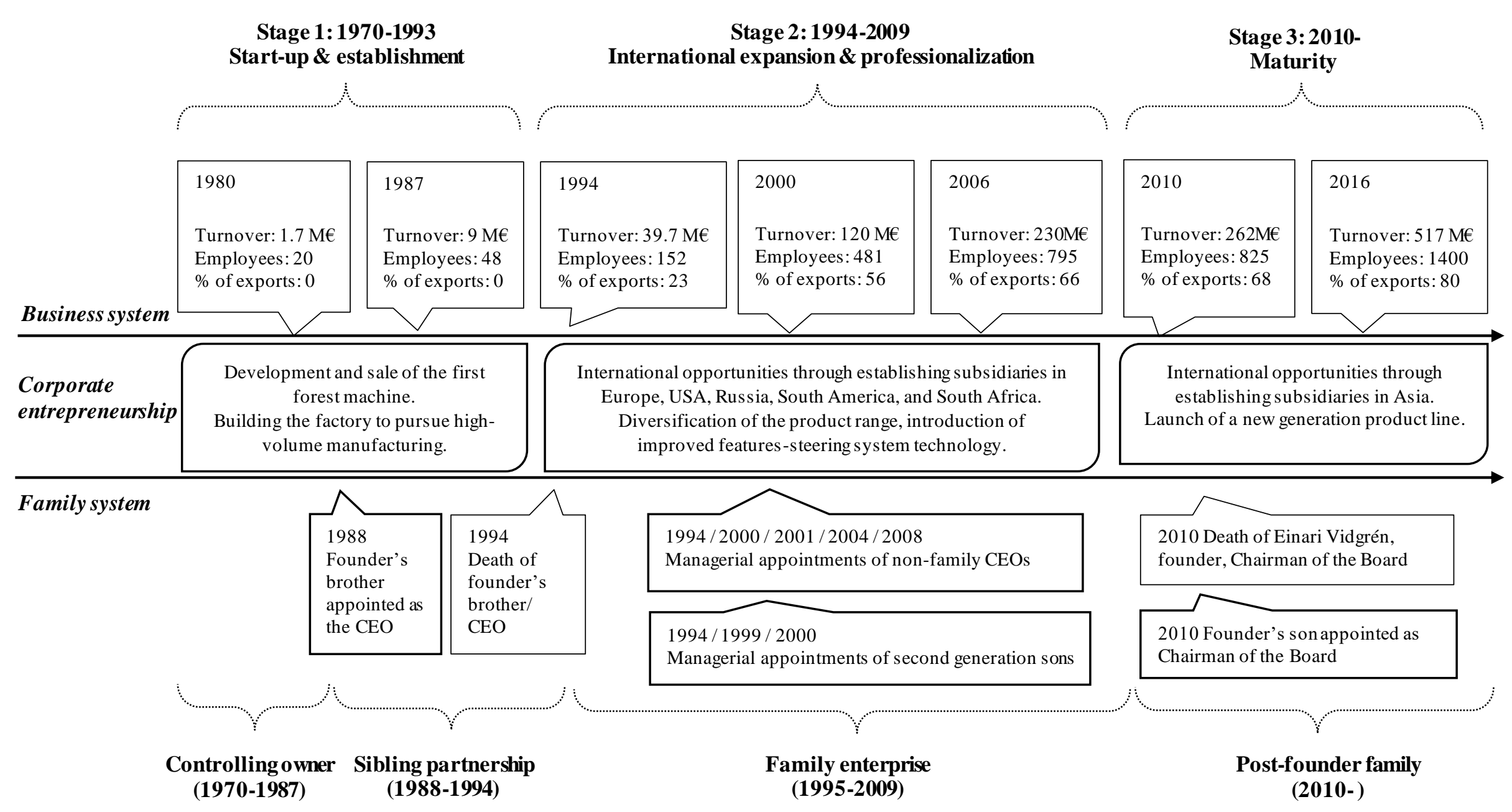

Figure 1. Evolution of the family and business systems at Ponsse Plc. 
- Questioning humbleness as the central ethos of the rural local community

- Unconsciously assuming the family values

$\bullet$

- Introduction ofnew business value

- Founder's perseverance and insistence on the new business value

work

- Founder's optimism and strongfaith in the future

- Founder projecting, communicating, and encouraging high performance expectations

Family dimension of values work:

Challenging one

locally rooted family value

Business dimension of values work:

Espousing business value

Temporal dimension of values work:

Envisioning the future

- Closeness to employees and the local community

- Strengthening the family influence in the firm

- Strong resistance againsthierarchy

- The centricityof "equality"

- Carefullylistening to localpeople

- Reviewing localpeople's experiences and expectations

- Reactivating the family value of "hard work"

- Collecting and sharing foundational stories

- Routinizing the business values that have become locally rooted

- Solid and leading position in the industry

- 2 nd generation acting on the family values

- 2nd generation demonstrating genuine engagement with the local rural community values work:

Screening the past and future

Family dimension of values work:

Espousing the family values

Business dimension of values work:

Rejecting the external business values

Temporal dimension of
Family dimension of values work:

Materializing family values

Business dimension of values work:

Normalizing business values

Temporal dimension of values work:

Embodying past values

Figure 2. Data analysis structure 


\section{APPENDIX}

Table II. Supporting evidence for "rooting": Mechanisms of values work and outcomes

\begin{tabular}{|c|c|}
\hline 2nd-order themes & First-order codes and selected evidence \\
\hline $\begin{array}{l}\text { Business dimension of values } \\
\text { work: } \\
\text { Espousing in dustry-embedded } \\
\text { business values }\end{array}$ & $\begin{array}{l}\text { Introduction of new business value. We respond to competition with a better product and better service (Einari Vidgrén, newspaperarticle, } 1985 \text {, } \\
\text { Miilu) } \\
\text { Founder's perseverance and insistence on the new business value. He [Einari Vidgrén] had good and fair relationships with his employees and } \\
\text { customers. That was highly significant for the development and future of the factory. They promised to fix any problems that the customers } \\
\text { ma chinesmight have. That promise was always kept, even if it meant working extra time at night (History of Ponsse, 2007, p.24) }\end{array}$ \\
\hline $\begin{array}{l}\text { Familydimension of values } \\
\text { work: } \\
\text { Challenging one locally rooted } \\
\text { family value }\end{array}$ & $\begin{array}{l}\text { Questioning "humbleness" as the central ethos of the rural local community. Einari said that we need to make a Mercedes-Benz of the forest } \\
\text { ma chines. And that sounded like a joke, how could we do it, because in the 1970s, Mercedes-Benz was world-class. But saying that, he made a new } \\
\text { rule, we need to do it (Owner, Chaiman of the Board) } \\
\text { Unconsciously assuming other family values. One has to remember that the first 10-15 yearsofPonsse's history were very modest and rocky. It } \\
\text { was hand-to-mouth. Through hard work they survived. (Interview, Product Manager) }\end{array}$ \\
\hline $\begin{array}{l}\text { Temporal dimension of } \\
\text { values work: } \\
\text { Envisioning the future }\end{array}$ & $\begin{array}{l}\text { Founder's optimismand strong faith in the future. Einari was surprisingly strong and hardy, his faith was strong and his motivation to work was } \\
\text { immense (History of Ponsse) } \\
\text { Founderprojecting, communicating, and encouraging high performance expectations. The spark to establish the company came from the desire } \\
\text { to build a machine that would be durable a nd long lasting. (Newspaper article, Miilu, 1980) }\end{array}$ \\
\hline $\begin{array}{l}\text { Outcome: } \\
\text { Temporary dominance of } \\
\text { business values enabling early } \\
\text { entrepreneurial growth }\end{array}$ & $\begin{array}{l}\text { Growing fame and economic growth. Suddenly, I had lots of people congratulating me and clapping me on my back, even the bank managers } \\
\text { started offering us money (Einari Vid grén, Newspaperarticle, 1985, Miilu) } \\
\text { Espousing business values. When we were negotiating the terms of our partnership, we were very impressed by Ponsse's innovativeness. So far, } \\
\text { we ha ven't been disappointed. (Manager at DaimlerChrysler, Newspaperarticle, 1985, Miilu) }\end{array}$ \\
\hline
\end{tabular}


Table III. Supporting evidence for "revitalizing": Mechanisms of values work and outcomes

\begin{tabular}{|c|c|}
\hline 2nd-order themes & rst-order codes and selected evidence \\
\hline $\begin{array}{l}\text { Business dimension of values } \\
\text { work: } \\
\text { Rejecting external business } \\
\text { values }\end{array}$ & $\begin{array}{l}\text { Strong resistance against "hierarchy". Some of the CEOs thought that they were somehow better than the rest of us. If you think like that you } \\
\text { ha ve to go. Mutual respect and trust between the management and employees is what the Ponsse spirit is all a bout. If the CEO thinks too highly } \\
\text { of him self, it has a hugeimpact on the company's spirit. If he walks a nd his nose is up in the air so that you can only see his nostrils. It doesn't } \\
\text { work like that here. Here all the people, welders, painters, and directors, are equal. (Interview, Supervisor) } \\
\text { The centricity of "equality". The late CEOs, neitherEsa nor Einari, ever considered themselves as any better than others, there was no hierarchy. } \\
\text { For instance, anybody could come and talk to Einari, a nd he would listen. He was easily approachable.(Interview, The firstemployee) }\end{array}$ \\
\hline $\begin{array}{l}\text { Familydimension of values } \\
\text { work: } \\
\text { Espousing family values }\end{array}$ & $\begin{array}{l}\text { Closeness to employees and the local community. Ponsse celebrates its } 40 \text { years of existence with open doors. It is a family event, where everyone } \\
\text { is invited (Newspapera nnouncement, } 2010 \text {, Milu). } \\
\text { Strengthening the family influence in the firm. My personal identity is very much rooted in Vieremä. When I interact with the people in the } \\
\text { villa ge, I can forget about the business challenges I have. I can cool down. (Interview, Owner and Chairman of the Board) }\end{array}$ \\
\hline $\begin{array}{l}\text { Temporaldimension of values } \\
\text { work: } \\
\text { Screening thepast and future }\end{array}$ & $\begin{array}{l}\text { Carefullistening tothe local people. Ponsse listens well to us. I have called Ponsse many times, and it is interesting how naturally they talk to } \\
\text { me. I feel like I am talking with a friend. Usually when you call a large firm'spresident, it is very difficult to talk. For Ponsse, everyone'sopinion } \\
\text { is important. (Interview, local resident) } \\
\text { Reviewing local peoples' experiences and expectations. People were calling him all the time, and he would alwaysanswer. Iasked whyhe always } \\
\text { answers, because many times people were asking for money or this or that }[\ldots] \text { He wanted to know what was happening. People were talking } \\
\text { about the company or the sales guys. There were lots of customers calling, local people calling. Also regarding people }[\ldots] \text { not like gossip but } \\
\text { close to that [...] (Owner, Chaiman of the Board) }\end{array}$ \\
\hline $\begin{array}{l}\text { Outcome: } \\
\text { Rebalancing family and } \\
\text { business values enabling locally } \\
\text { rooted international } \\
\text { entrepreneurship }\end{array}$ & $\begin{array}{l}\text { Firing of culturally incompatible non-family CEOs. After Esa's death [name] started as CEO. He was a tough salesman. He knew a lot about } \\
\text { exporting and forcefully developed sales and marketing. In ' } 95 \text { and ' } 96 \text { he opened new subsidiaries. It was his capabilities and vigour that made } \\
\text { us international }[\ldots] \text { But the culturesdidn't match. He wasa business director looking only forgrowth. (Interview,Product Manager) } \\
\text { Hiring locally a ssimilated and accepted CEO. The CEO is in charge of the village as well. The way he acts, his 'face' as a first person to follow. } \\
\text { Our lea der needs to be flexible, easy-going, and 'village-like'. (Interview, HR Manager) }\end{array}$ \\
\hline
\end{tabular}


Table IV. Supporting evidence for "spreading": Mechanisms of values work and outcomes

\begin{tabular}{|c|c|}
\hline mes & t-order codes and selected evidence \\
\hline $\begin{array}{l}\text { Business dimension of values work: } \\
\text { Normalizing business values }\end{array}$ & $\begin{array}{l}\text { Routinizing the business values that have become locally rooted. Something that Einari introduced and that has been kept is the courage to } \\
\text { do things. Ithas disseminated but one has to feed it and strengthen it constantly. Now that we have accumulated more knowledge and success } \\
\text { it's ea sier. We can do it just like we have been able to do it before. Success feeds it. Weare good. The location of the company does not make } \\
\text { someone else better than others(Interview, Product Manager) } \\
\text { Solid and leading positionin the industry. We have to develop our products constantly. We have to be on the forefront in every aspect like } \\
\text { welding, machinery, finishing, a nd electronics [...] If you stop others will ca tch up. But yes, we are the best, there is no doubt about it } \\
\text { (Interview,Supervisor) }\end{array}$ \\
\hline $\begin{array}{l}\text { Family dimensionof values } \\
\text { Ma terializing family values }\end{array}$ & $\begin{array}{l}\text { Reactivating the family value of "hard work". I think in this time of individualism, when you can put yourhat on, just enjoy yourself, life is } \\
\text { good, and you don't need to eat everything. It's okay just to leave the dirty plates here. Somebody else will clean it up [...] I'm very old- } \\
\text { fa shioned so I hate those situations during the family dinner or elsewhere when this happens. So I like the rules we have in the company to } \\
\text { keep the places clean, the safety rules [...] and how we treat customers, how we treat employees, how we do things in the old way. (Interview, } \\
\text { Owner and Chairman of the Board) } \\
\text { Collecting and sharing foundational stories. I managed to scan all the photos of an elderly person in the village.I listened to his stories for } \\
\text { two years before he passed away [...] Based on photos and stories, I could rebuild Einari's childhood home. I wanted to remind people of } \\
\text { what life was like back then. It was a lotsimpler. People didn'thave toilets or saunasinside.It was important to live economically and work } \\
\text { hard. (Interview, Owner and Chairman of the Board) }\end{array}$ \\
\hline $\begin{array}{l}\text { Temporaldimension of valu } \\
\text { work: } \\
\text { Embodying past values }\end{array}$ & $\begin{array}{l}\text { lgeneration acting onthe family values. We have to talk about the values constantly a nd show example - it worksin any culture (Jarmo } \\
\text { grén, newspaper article, Yrittäjä 2017). } \\
\text { l generation demonstrating genuine engagement with the local rural community. Juha is very patriotic, just likeEinari. He knows about } \\
\text { rything that is happening in the village (Interview, Marketing Assistant) }\end{array}$ \\
\hline $\begin{array}{l}\text { Outcome: } \\
\text { Spreading the family values } \\
\text { inspiring continued entrepreneurial } \\
\text { behaviour in a mature family firm. }\end{array}$ & $\begin{array}{l}\text { The family values becoming instilled the younger generation. Today's generation also knows about these stories. I think it is nice that the } \\
\text { firm tells about the origins of the firm, a nd today's generation respects the achievementsof the older generation. For humans, it is extremely } \\
\text { important to know the roots and history. (Interview; Shopkeeper) } \\
\text { The family values spreading. The Einari Vidgrén Memorial Foundation that was established cherishes the memory of our father and aims to } \\
\text { continue to strengthen the local community spirit and support the different functions and activities in the village that were important to him } \\
\text { (Newspaper article, 2012, Miilu) }\end{array}$ \\
\hline
\end{tabular}

